\title{
Labour-Intensive Services and Changes in Value Added Tax Revenue
}

\author{
- Krqikallová Katerina, Strílková Regína
}

\begin{abstract}
VAT rates have gradually become an important fiscal policy tool of of EU member states. This paper quantifies the influence on the VAT revenue of the potential transfer of selected labour intensive services from the standard to a reduced VAT rate in the Czech Republic. The data used for the analysis were obtained by a questionnaire, as well as through research performed at the General Financial Directorate and the Czech Statistical Office. To analyze the data, a comparison analysis and descriptive statistical methods were used. The change in VAT rate would cause a decrease in VAT revenue up to 1.6 billion CZK per year, but it would also bring positive effects, especially in the business development of the suppliers of labor intensive services. It could also prevent a price increase during the planned introduction of the e-sales system in restaurants.
\end{abstract}

Keywords: European Union tax policy, labour-intensive services, value added tax, value added tax rates, value added tax revenues, Crech Republic

JEL Classification: D22, H21, H22, H32

\section{INTRODUCTION}

Value added tax (hereinafter referred to as VAT) has become an important tool of fiscal policy worldwide since its introduction (Tait, 1988; James, 2015). Since direct taxes revenue has tendency to decrease, on the contrary the VAT revenue has more increasingly important proportion on the EU states' revenues. An exceptional position of VAT rates is also used as a tool of encouragement of supplying of specific categories of goods and services that could bring subsequent effects to the economy as in case of possibility of application of reduced VAT rates to labourintensive services. That is the reason why the application of VAT rates has been a long discussed topic within the EU. Generally, the current trend in the European Union is rather an increasing of VAT rates (European Commission, 2015).

Anyway, Bye, Strom and Avitsland (2012) found by the research carried out in Norway that general and uniform VAT system covering all goods and services without exemptions is welfare superior to current and former non general and non-uniform Norwegian system. Similar results were obtained by Buettner and Erbe (2014) when they quantified the estimates of the effects of repealing the VAT exemption of financial services in Germany.

In addition, the Czech Republic has been considering for a longer time, in accordance with the Council Directive 2009/47/EC of 5 May 2009 amending Directive 2006/112/EC as regards reduced rates of VAT, the application of a reduced VAT rate (now the first reduced rate on the 15\% level) for the selected labour-intensive services for which there is still applied the standard rate. Specifically, the restaurant and catering services, hairdressing services, minor repairing of shoes and leather goods and minor repairing of bicycles. 
Currently, the debates has been taking place in the Chamber of Deputies on the Government draft law amending certain laws in relation with the adoption of the law on records of sales. This is Parliamentary press No. 514. A part of the Government draft law is a transfer of restaurant and catering services to the first reduced VAT rate, since for these services there should be introduced the system of the electronic records of cash sales in the first wave. The system (for more information about implementation of this system in Croatia see Tot and Detelj (2014)) as a new tool in the fight against tax evasion (the problem of tax evasion is dealt in detail also by Manea \& Manea, 2011; Bieliková, Buňo \& Hrašková, 2015) should be successively implemented since 2016 (Chamber of Deputies of the Parliament of the Czech Republic, 2015).

In contrast to the Czech Republic, a majority of the EU Member States applied the reduced rate at least to some of the above mentioned services. Studies carried out within these countries evaluated that this legislative change did not always lead to the anticipated positive effect, especially in terms of pricing policy of these services suppliers and state budgets. More positive indicators were generally reported in the area of business investment or increasing of the profit but less in increasing of employment in the selected sectors. Another approach to the empirical analysis of impact of taxes other than income taxes on the corporate investment is brought by Buettner and Wamser (2009). Jensen and Schjelderup (2011) have also focused on indirect taxation and tax incidence under nonlinear pricing in their research. These included e.g. the application of a reduced rate to restaurant services in France, where the beneficial effect was also reflected in a decrease in unemployment (for more information see, e.g. Ministry for the Economy, Industry and Employment France, 2010; Ministére de L'Artisanat du Commerce et du Tourisme, 2012). Furthermore, Finland, where the price reduction was reflected mainly in large companies, suppliers of hairdressing services and restaurants that were a part of an association of suppliers of restaurant services MaRa (see Kosonen, 2013; Kosonen \& Harju, 2013). In case of Belgium, there was an increase in number of jobs and business investment (for more information see Goos, Konings \& Breemersch, 2013). In Germany, the VAT rate applied to restaurant services was reduced in 2010, which led to an increase of investment in the sector and a slight increase of job vacancies (Lomas, 2010). The reduction of VAT rates in the sector of hotel and restaurant services was also considered in Italy. The results of the study showed an increase in consumption of accommodation services, a slight decrease in prices and increase of number of new jobs. Despite the positive aspects, however, there would be a decline in VAT revenues (Manente \& Zanente, 2010).

The paper is focused on quantification of impact of possible transfer of above mentioned selected labour-intensive services from the standard to the reduced VAT rate on VAT revenue in the conditions of the Czech Republic.

\section{THEORETICAL BACKGROUND}

VAT is a general consumption tax which the taxpayer, the final consumer pays included in the price of purchased goods and services (James \& Nobes, 2010). The VAT payer pays tax on the output of the taxable supply, while claiming deduction of the received taxable supplies in order to realize this taxable supply (Platteeuw \& Pestana, 2011). Every supplier of goods or services pays the tax only on the value that he added to his or her activity. 
The general provisions regulating the issue of VAT rates applied in the EU Member States are contained in Articles 93 to 130 of the Council Directive 2006/112/EC of 28 November 2006 on the common system of the VAT (hereinafter referred to as VAT Directive) and its relevant Annexes. The provisions referred that the supplies of goods and services are usually subject to the standard VAT rate of at least 15\% (Annacondia \& Corput, 2013). Furthermore, the Member States are allowed to apply one or two reduced rates of at least $5 \%$, but only for a limited range of goods and services (Schenk, Thuronyi \& Cui, 2015).

An application of reduced VAT rates on labour-intensive services has been an actual topic for a long time. The labour-intensive services have limited ability to innovate (they cannot benefit from technological progress as much as other sectors) and therefore have relatively high costs per unit of labour.

In this context, within the originally three-year experiment there was adopted Council Directive 1999/85/EC concerning VAT on labour-intensive services (category minor repairs of bicycles, shoes and leather goods, renovations and repairs of private dwellings, cleaning in private households, domestic care services and hairdressing), which allowed, since 1 January 2000, to apply a reduced VAT rate to certain specified labour-intensive services, but only for an experimental period, so that it could be possible to test the impact, in terms of job creation and in combating the "black market economy". Originally a three-year experimental period was prolonged several times until the end of 2010.

The European Commission had to prepare a report for evaluation of this experiment for the European Parliament. The required evaluation report was prepared in May 2007 by a group of independent economic experts from the Copenhagen Economics company as a "Study on reduced VAT applied to goods and services in the Member States of the European Union" (hereinafter CE study). Key results showed, as stated in Copenhagen Economics (2007), that the economic impact of the transfer of services from the standard to the reduced VAT rate envisaged an increasing of productivity, gross domestic product, employment, wages and lower prices of services. Higher wages and lower prices should bring an increase in consumption in the EU, which would lead to an increase in demand for these goods and services. This study also assumes that SMEs will be able to enter the market thanks to the released barriers, through which the large companies have the opportunity to keep prices unreasonably high, the opportunity to enter the market. Other assumptions include the shift from a so-called grey economy and "do it yourself activities" into the legal taxable sphere. Based on the results of this report and other consultations, the European Commission concluded that the application of reduced VAT rate for labour-intensive services which are intended for the local market, poses no real threat to the functioning of the internal market.

For these reasons, Council Directive 2009/47/EC of 5 May 2009 amending Directive 2006/112/ EC as regards reduced rates of value added tax (hereinafter "Directive 2009/47/ EC") which entered into force on 1 June 2009. Directive 2009/47/ EC allows the Member States of the European Union to include the selected services within a reduced tax rate without a time limit. In addition to the previously mentioned services, there are also a restaurant and catering services and delivery of books on any medium. 
The proof of the persistent relevance of the VAT rates topic in the European Union are two public discussions that the European Commission launched to this given subject. First, a consultation entitled "Green Paper on the future of VAT. Simpler, more robust and efficient VAT system." was launched in 2010 (European Commission, 2010) and later it was followed by debate in 2012 entitled "Review of existing legislation on reduced VAT rates". The purpose of these public consultations was according to the European Commission (2012) collecting of relevant opinions, evidences and recommendations of the general public, especially among professionals in order to help the European Commission to develop reflection in this field. The results of those discussions, similarly to the results of the CE study from 2007, led to the recommendations for the Member States to apply the reduced VAT rates for selected commodities and services including the labour-intensive ones which are intended for the local market (Copenhagen Economics, 2007).

\section{OBJECTIVES AND METHODOLOGY}

The goal of this paper is to quantify the foreseeable impact of a potential transfer of above mentioned selected labour-intensive services from the standard to the reduced VAT rate on VAT revenues in the conditions of the Czech Republic.

The data for the primary empirical research were obtained by the questionnaire research carried out among suppliers of these services in the Moravian-Silesian Region of the Czech Republic. Last but not least, mainly for the more advanced analysis, there were used the data from the Czech Statistical Office and the General Financial Directorate of the Czech Republic (GFD).

Based on the assumption of approximate similarity of selected labour-intensive services suppliers' attitudes throughout the Czech Republic, it is possible to apply correctly a coefficient (see equation 1) with negligible distortion, the coefficient was used to analyze potential changes in VAT collection in terms of Moravian Silesian Region (Krzikallová \& Stř́lková, 2015).

On the one hand, the questionnaire contains the actual data for the taxable period of 4th calendar quarter of the 2010 or in case of month taxable period - December 2010. On the other hand, it contains the data that are presupposed by the VAT payer in case of the transfer of these services from the standard to the reduced VAT rate. Respondents, who were not registered to VAT, reported the data that would be demonstrated in a situation if they were VAT payers.

The analysis that is contained in this paper was prepared using the data included in the questionnaire related to VAT liability. Specifically: sales excluding VAT, costs excluding VAT, output tax according to VAT rates, input tax according to VAT rates and tax liability. Presupposed data of the respondents involved aspects of changes in labour productivity, number of employees, labour costs, trade margin, and investment in business development or potential increase of demand of their services.

The transfer of the labour-intensive services from the standard to the reduced VAT rate could increase the competitiveness of the suppliers of these services in the current conditions of the Czech Republic. For more information about impact of potential VAT rates changes on the behavior of suppliers of these services, see Randová and Krajňák, 2012; Randová, Krajňák and Friedrich, 2013. 


\subsection{Determination of the sample of the respondents}

Prior to starting the very research, it was necessary to determine the sample size in such a way to get results to at least average reliability and accuracy (Sudman, 1976). The process of determination of the sample size was expressed in detail in Randová \& Krajňák, 2013.

Tab. 1 - Population and sample size according to the subgroups. Source: Authors' calculations according to data from the Czech Statistical Office.

\begin{tabular}{|l|c|}
\hline Population & $\begin{array}{c}\text { Sample size } \\
\text { (number of respondents) }\end{array}$ \\
\hline Restaurant Services & 161 \\
\hline Hairdressing Services & 84 \\
\hline Minor repairing of shoes and leather goods & 36 \\
\hline Minor repairing of bicycles & 36 \\
\hline Total & 317 \\
\hline
\end{tabular}

\subsection{Procedure of recalculating of VAT liability change of the respondents}

The data provided by the General Financial Directorate involved information about the VAT liability of suppliers of the analyzed services in total for each calendar year, but they were not classified according to each tax period. As it has been already mentioned, the respondents provided data for the last tax period of the year 2010 (a month or a quarter, depending on the VAT payer type).

For the comparability of data and for achieving the aim of this paper, the recalculation was made of the data obtained by the questionnaire research on the data per year. The real and estimated VAT liability of each respondent for the referred tax period was at first multiplied by the number of VAT returns that the respondent submits per year (four in case of quarterly VAT payer and twelve in case of monthly VAT payer). Subsequently, the average real and estimated VAT liability by individual categories of the respondents was calculated. The identified average real and estimated VAT liability was multiplied by the number of respondents in each category. This was a way of determining the recalculated sum of real and estimated VAT liability of the respondents was determined for the year that the questionnaire research was carried out (2010).

The change of average recalculated VAT liability (coefficient) in the year that the questionnaire research was carried out (2010) was calculated as ratio of recalculated estimated and recalculated real annual VAT liability of all respondents according to equation (1)

$\Delta V A T(L R)_{0}=\frac{\Sigma V A T(L R)_{0}^{e}}{\Sigma V A T(L R)_{0}^{r}}$,

where

$\triangle V A T(L R)_{0}$ - is a recalculated average annual VAT liability change of the respondents in the year that the questionnaire research was carried out (coefficient),

$\Sigma V A T(L R)_{0}^{e}$ - is a recalculated sum of estimated VAT liability of all respondents in the year that the questionnaire research was carried out, 
$\Sigma \operatorname{VAT}(L R)_{0}^{r} \quad$ - is a sum of recalculated real VAT liability of all respondents in the year that the questionnaire research was carried out.

The coefficient was rounded to four decimal places for the purpose of the calculations.

Procedure of recalculating of VAT liability change (a potential VAT revenue of the Czech republic)

Subsequently, the data about real reported annual VAT liability (a potential VAT revenue) of the Czech Republic obtained from the General Financial Directorate were multiplied by the coefficient (a recalculated average VAT liability change) in each year. The same coefficient was used because of the fact that owing to the persistence of the global economic crisis in the analyzed periods, there is not expected a significant change in the behaviour of the respondents, suppliers of the services or their customers. Since the VAT rates were different in each analyzed period, to reflect this fact the recalculated VAT liability of the each analyzed year was determined according to equation (2)

$\operatorname{VAT}\left(L_{x}^{e}\right)=\Delta V A T(L R)_{0} \cdot \operatorname{VAT}(L R)_{x} \cdot\left(\frac{V A T\left(R_{x}^{S}\right)-V A T\left(R_{x}^{r}\right)}{\operatorname{VAT}\left(R_{0}^{S}\right)-V A T\left(R_{0}^{r}\right)}\right)$,

where

$\operatorname{VAT}\left(L_{x}^{e}\right) \quad$ - is the recalculated estimated VAT liability of the analyzed year,

$\triangle V A T(L R)_{0}$ - is the recalculated average annual VAT liability change of the respondents in the year that the questionnaire research was carried out (coefficient),

$\operatorname{VAT}(L R)_{x^{\prime}}$ - is the real VAT liability of the analyzed year,

$\operatorname{VAT}\left(R_{x}^{S}\right) \quad$ - is the standard VAT rate of the analyzed year,

$\operatorname{VAT}\left(R_{x}^{r}\right)^{\prime} \quad$ - is the reduced VAT rate of the analyzed year,

$\operatorname{VAT}\left(R_{0}^{S}\right) \quad$ - is the standard VAT rate of the year of questionnaire research was carried out,

$\operatorname{VAT}\left(R_{0}^{r}\right)$. - is the reduced VAT rate of the year that the questionnaire research was carried out.

The potential change of VAT liability (VAT revenue) in individual years was calculated according to equation (3)

$\Delta \operatorname{VAT}\left(L_{x}^{e}\right)=\operatorname{VAT}(L R)_{x}-\operatorname{VAT}\left(L_{x}^{e}\right)$,

where

$\Delta \operatorname{VAT}\left(L_{x}^{e}\right)$ - is the change of VAT liability (VAT revenue) of the analyzed year,

$\operatorname{VAT}(L R)_{x}$ - is the real VAT liability of the analyzed year,

$\operatorname{VAT}\left(L_{x}^{e}\right): \quad$ - is the recalculated estimated VAT liability of the analyzed year.

Procedures for data processing and analysis by mathematical and statistical methods are recommended e.g. by Anderson, Sweeney \& Williams, 2011; Buglear, 2012; Newbold, Carlson \& Thorne 2013. 


\section{RESULTS}

This part of the paper contains deeper analysis of changes of VAT liability of all of the selected categories of labour-intensive services suppliers, especially the impact of potential transfer of these services from the standard to the reduced VAT rate on the VAT liability of the suppliers and a potential impact on VAT revenue in conditions of the Czech Republic.

\subsection{Calculation of an average change of VAT liability (potential VAT revenue of Moravian-Silesian Region and the Czech Republic)}

By recalculating the data obtained by the questionnaire research, it was found that suppliers of services in the sample of Moravian-Silesian Region declared following changes in the average VAT liability, as shown in Tab. 2.

Tab. 2 - An average change of VAT liability annually and respondent in Moravian-Silesian Region in the year of questionnaire research in 2010. Source: Authors' calculations according to the questionnaire research.

\begin{tabular}{|l|c|c|c|}
\hline $\begin{array}{l}\text { Suppliers of labour- } \\
\text { intensive services }\end{array}$ & $\begin{array}{c}\text { Average real VAT } \\
\text { liability (CZK) }\end{array}$ & $\begin{array}{c}\text { Average estimated } \\
\text { VAT liability (CZK) }\end{array}$ & $\begin{array}{c}\text { Average change of } \\
\text { VAT liability (p.p.) }\end{array}$ \\
\hline Restaurant services & 543678.47 & 218341.39 & 60 \\
\hline Hairdressing services & 87870.18 & 5021.09 & 94 \\
\hline $\begin{array}{l}\text { Repairing of shoes } \\
\text { and leather goods }\end{array}$ & 46152.67 & -13084.33 & 128 \\
\hline Repairing of bicycles & 85401.89 & -7597.67 & 109 \\
\hline
\end{tabular}

As it is clear from results in Tab. 2, it was found by questionnaire research that suppliers of restaurant services would estimate an average VAT liability decrease by 60 p.p. in comparison with the originally declared liability, suppliers of hairdressing services by 94 p.p. Suppliers of category repairing of shoes and leather goods would expect creation of an excess VAT deduction, therefore, they would assume an average VAT liability decrease by 128 p.p. and suppliers of repairing of bicycles by 109 p.p. The procedure of recalculating of VAT liability change of the respondents is contained in the Chapter 3.2. The results of the calculation of the coefficient according to equation (1) are shown in Tab. 3.

Tab. 3 - The change of average recalculated VAT liability of the respondents (coefficient). Source: Authors' calculations according to the questionnaire research.

\begin{tabular}{|l|c|c|c|}
\hline $\begin{array}{l}\text { Suppliers of labour- } \\
\text { intensive services }\end{array}$ & $\begin{array}{c}\Sigma V A T(L R)_{0}^{r} \\
(\mathrm{CZK})\end{array}$ & $\begin{array}{c}\Sigma V A T(L R)_{0}^{e} \\
(\mathrm{CZK})\end{array}$ & $\begin{array}{c}\Delta V A T(L R)_{0} \\
\text { (coefficient) }\end{array}$ \\
\hline Restaurant services & 87532234 & 35152964 & 0.4016 \\
\hline Hairdressing services & 7381095 & 421771 & 0.0571 \\
\hline $\begin{array}{l}\text { Repairing of shoes } \\
\text { and leather goods }\end{array}$ & 1661496 & -471036 & -0.2835 \\
\hline Repairing of bicycles & 3074468 & -273516 & -0.0890 \\
\hline
\end{tabular}


Through a process referred to in Chapter 3.3 of the article, using equation (2) the recalculation was done of really declared VAT liability (potential VAT revenue) to VAT liability that would have been declared in the case of the mentioned legislative change in individual years in the selected categories of analyzed services. The quantification was made for the period of years 2005 to 2013.

\subsection{Results of the restaurant services category}

Fig. 1 shows that the potential transfer of restaurant services from the standard to the reduced VAT rate would cause a significant decrease of VAT liability in this category. This drop could possibly be eliminated by introducing the above mentioned e-sales system. The decrease of the potential VAT revenue in this category is reflected in the approximate range of 482 million to 1.6 billion CZK annually. The biggest change would arise in case of the possible legislative change in 2008 .

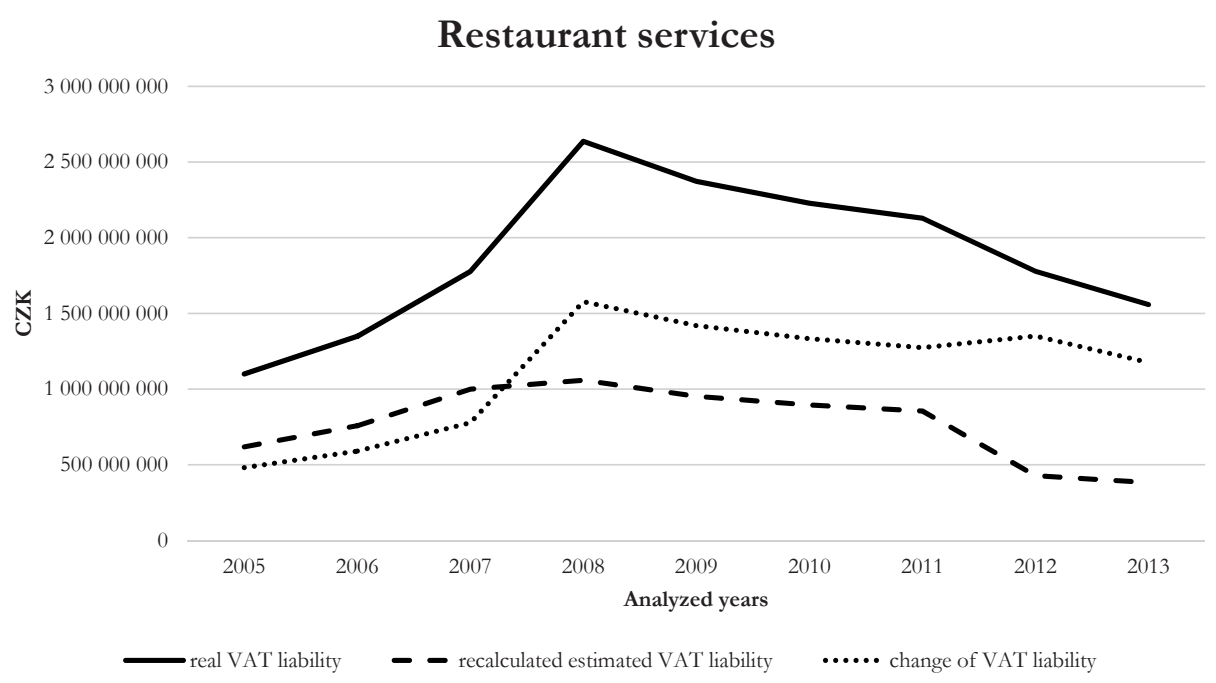

Fig. 1 - Real and recalculated estimated VAT liability of restaurant services. Source: Authors' calculation according to the questionnaire research and GFD.

\subsection{Results of the hairdressing services category}

Fig. 2 illustrates very clearly that the transfer of hairdressing services from the standard to the first reduced VAT rate would mean a significant reduction of VAT liability of this category and thus a decrease in VAT revenue which is reflected in the range of about 87 to 122.5 million CZK annually. The biggest drop would occur in case of the mentioned legislative change in 2013, when there was also expressed the highest real VAT liability. In this year, there was also declared the highest real VAT liability of suppliers of these services. 


\section{Hairdressing services}

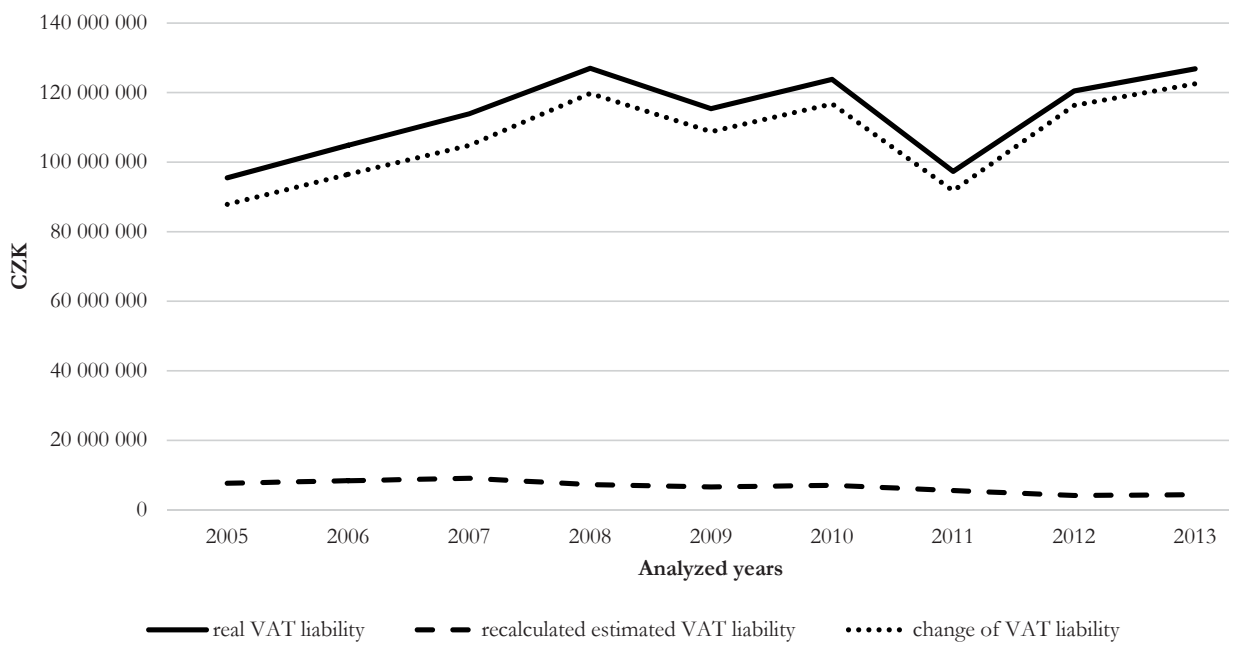

Fig. 2 - Real and recalculated estimated VAT liability of hairdressing services and its change. Source: Authors' calculation according to the questionnaire research and GFD.

\subsection{Results of the category of minor repairing of shoes and leather goods}

In case of another analyzed category of suppliers of minor repairing of shoes and leather goods, it is clearly evident in Fig. 3 that there is the rapid drop of the real VAT liability (VAT revenue) to the approximately value of 9 million CZK. Subsequently in 2010 in this category there is a slight increase of VAT revenue and the trend continues for the rest of analyzed periods. In 2013, the VAT revenue gets nearer the value of the year 2008 which was the highest in the analyzed periods, it means about 13.9 million CZK.

If there was a transfer of these services from the standard to the first reduced VAT rate, there would be created excess VAT deductions therefore the VAT revenue would be negative. The biggest differences would occur in the periods of years 2007 and 2008 in which the highest real VAT liabilities were declared. The annual decrease of VAT liability would be reflected in the range of 11.6 to 19.2 million CZK. 


\section{Minor repairing of shoes and leather goods}

25000000
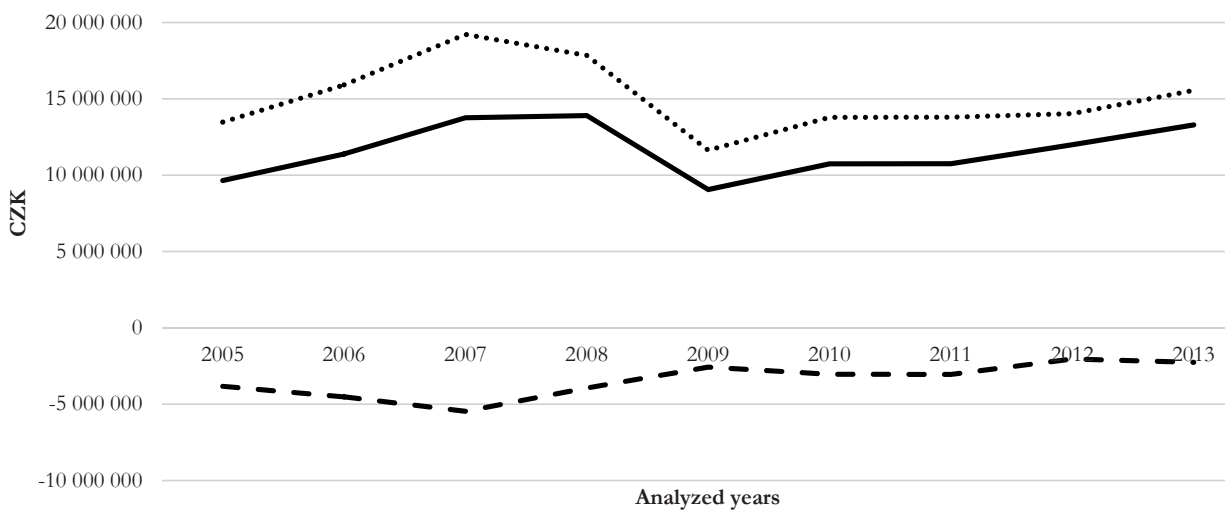

- real VAT liability $\quad$ - $\quad$ recalculated estimated VAT liability $\quad \ldots .$. change of VAT liability

Fig. 3 - Real and recalculated estimated VAT liability of repairing of shoes and leather goods and its change. Source: authors' calculation according to the questionnaire research and GFD.

\subsection{Results of the category of repairing of bicycles}

As with the category of minor repairing of shoes and leather goods, the category of repairing of bicycles would start to create an excess VAT deductions so that the VAT revenue would be negative in case of the already mentioned potential legislative change. As it is clear from Fig. 4, the suppliers of these services declared, unlike in the other analyzed years, significantly higher real VAT liability in 2010. Regardless of this fact, the category of repairing of bicycles in case of transfer of these services to the first reduced VAT rate, would report very similar results of the recalculated estimated VAT liability (potential VAT revenue) in each analyzed period.

For the foregoing reason, the biggest change of presupposed VAT liability and the highest drop of VAT revenue would occur in 2010, approximately by 194 mil. CZK, see Fig. 4. The decrease of VAT liability in the analyzed periods would be reflected in the range of about 60 to 194 million CZK. 


\section{Repairing of bicycles}

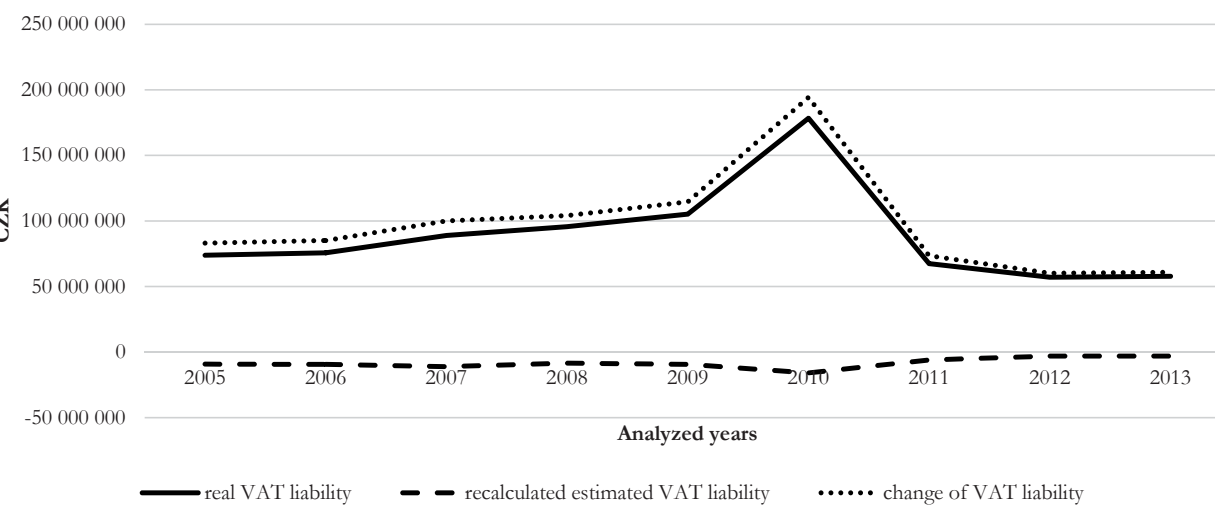

Fig. 4 - Real and recalculated estimated VAT liability of repairing of bicycles and its change. Source: Authors' calculation according to the questionnaire research and GFD.

\section{DISCUSSION AND CONCLUSION}

VAT is a substantial part of tax revenues in the Czech Republic. The issue of application of reduced VAT rates on the selected labour-intensive services is a long term discussed topic in the Czech Republic. That is why the authors have also decided to focus on the analysis of influence of this possible legislative change on the VAT revenue. Although it is clear, at the first sight, that this legislative change would have a negative impact on the VAT revenue, in the opinion of the authors it should be useful when deciding about the application of VAT rates to take into account other aspects such as investment into the business.

The transfer of the restaurant services from the standard to the reduced VAT rate would be reflected by the decrease of the VAT revenue in the range of about 482 to 1.6 billion CZK annually in the analyzed years from 2005 to 2013. The VAT revenue in case of category hairdressing services would decrease approximately by 87 to 122.5 mil. CZK per year. Suppliers of minor repairing of shoes and leather goods would recorded a drop of VAT liability in the range of about 11.6 million and 19.2 million per year. Category of suppliers of repairing of bicycles decrease of 60 to 194 million CZK. Both the last mentioned categories would become to report the excess VAT deductions in the each year.

According to the authors' opinion, the government should transfer at least restaurant and catering services to the first reduced VAT rate, since a reduced VAT rate is applied to most of their inputs, which leads in high proportion to their high VAT liability. This legislative change also could help to reduce tax evasion in a form of reduction of revenues and avoidance of exceeding a turnover for compulsory registration to VAT. Particularly in the situation when the limit for the compulsory registration is maintained at the level of one million CZK for twelve consecutive calendar months. For more about threshold limit value for the VAT registration see 
Sobotovičová, Blechová \& Janoušková, 2013. The potential legislative change might also lead to the elimination of price increase in restaurants in case of introducing the system of Electronic records of cash sales.

The authors are also aware of the fact that the results of this paper represent only one of possible ways of quantification of the impacts of this possible legislative change on VAT revenue. For another statistical approach to taxes evaluating see also e.g. Friedrich, Maková \& Široký, 2012; Krajňák, 2015. This problem has been analyzed in many Member States and each analysis brought different results. Compare for example Goos, Konings, \& Breemersch, 2013 and Lomas, 2010 in case of Germany or in case of Finland see Kosonen, 2013 and Kosonen \& Harju, 2013. Due to these reasons, in authors' opinion, this problem deserves further research.

\section{References}

1. Annacondia, F. \& Corput, W. (2013). EU VAT Compass 2013/2014. Amsterdam: IBFD.

2. Anderson, D. R., Sweeney, D. J., \& Williams, T. A. (2012). Modern business statistics with Microsoft Office Excel. Mason, OH: South-Western Cengage Learning

3. Bieliková, A., Buňo, M., \& Hrašková, D. (2015). Tax evasion related to VAT. Socio-economic aspects of economics and management: collection of scientific articles. 1 (2), 175-178.

4. Bye, B., Strom B., \& Avitsland, T. (2012). Welfare effects of VAT reforms: a general equilibrium analysis. International Tax and Public Finance, 19 (3), 368-392. doi:10.1007/s10797011-9193-9

5. Buettner, T., \& Wamser, G. (2009). The impact of nonprofit taxes on foreign direct investment: evidence from German multinationals. International Tax and Public Finance, 16 (3), 298-320. doi:10.1007/s10797-008-9063-2

6. Buettner, T., \& Erbe, K. (2014). Revenue and welfare effects of financial sector VAT exemption. International Tax and Public Finance, 21 (6), 1028-1050. doi:10.1007/s10797-0139297-5

7. Chamber of Deputies Parliament of the Czech Republic. (2015). Document of the Chamber No. 514. Prague: Chamber of Deputies Parliament of the Czech Republic. Retrieved from http://www.psp.cz/sqw/historie.sqw?o $=7 \& \mathrm{t}=514$

8. Copenhagen Economics. (2007). Study on reduced VAT applied to goods and services in the Member States of the European Union. Copenhagen: Copenhagen Economics.

9. European Commission. (2010). Green Paper on the future of VAT - Towards a simpler, more robust and efficient VAT system. Retrieved February 6, 2015, from http://ec.europa.eu/taxation_ customs/common/consultations/tax/2010_11_future_vat_en.htm

10. European Commission. (2012). Review of existing legislation on VAT reduced rates. Retrieved February 6, 2015, from http://ec.europa.eu/taxation_customs/common/consultations/ tax/2012_vat_rates_en.htm

11. European Commision. (2015). VAT Rates Applied in the Member States of the European Union. Situation at 1st September 2015. Retrieved September 9, 2015, from http://ec.europa.eu/ taxation_customs/resources/documents/taxation/vat/how_vat_works/rates/vat_rates_ en.pdf 
12. Friedrich, V., Maková, K. \& Široký, J. (2012). Testing the Predicative Ability of the Tax Progressiveness Indices. E a M: Ekonomie a Management, 15 (1), 2-13.

13. Goos, M., Konings, J. \& Breemerch, K. (2013). Een economische analyse van arbeidsintensieve sectoren. Horeca Vlaanderen. Retrieved February 6, 2015 from http://www.

fedhorecavlaanderen.be/downloads/news/9Uy2yGvYWGPIRzDO.pdf

14. James, K. (2015). The Rise of the Value Added Tax. New York: Cambridge University Press. doi:10.1017/cbo9781107358522

15. James, S. \& Nobes, Ch. (2010). The Economics of Taxation. Principles, Policy and Practice. Birmingham: Fiscal Publications.

16. Jensen, S., \& Schjelderup, G. (2011). Indirect taxation and tax incidence under nonlinear pricing. International Tax and Public Finance, 18 (5), 519-532. doi:10.1007/s10797-011-9167-y

17. Kosonen, T. (2013). More Haircut after VAT Cut? On the Efficiency of Services Sector Consumption Taxes. Helsinki: VATT - Government Institute for Economic Research. doi:10.2139/ ssrn. 2334084

18. Kosonen, T. \& Harju, J. (2013). Restaurant VAT Cut: Cheaper Meal and More Service? Helsinki: VATT - Government Institute for Economic Research. doi:10.2139/ssrn.2338434

19. Krajňák, M. (2015). Development of an Effective Tax Rate and other Selected Indicators of Personal Income Tax in Years 1993 - 2014. In Proceedings of the 7th International Scientific Conference Finance and the Performance of Firms in Science, Education, and Practice. (pp. 738-752). Zlín: Tomas Bata University in Zlín.

20. Krzikallová, K. \& Stř́lková, R. (2015). Value Added Tax Rates Applied to LabourIntensive Services and Impact of their Changes on the VAT Revenue. In Proceeding of the 7 th International Scientific Conference Finance and the Performance of Firms in Science, Education, and Practice. (pp. 779 - 794). Zlín: Tomas Bata University in Zlín.

21. Lomas, U. (2010). German Hoteliers Failed to Pass the VAT Reduction. Retrieved February 6, 2015, from http://www.tax-news.com/news/German_Hoteliers_Fail_To_Pass_On_VAT_ Reduction_41129.html

22. Manea, A. C. \& Manea, L. (2011) Cooperation between EU Member States to Prevent International Tax Evasion and Fraud. In Legal Practice and International Law: Proceedings of the International WSEAS Conference. (pp. 235-240). Brasov: WSEAS Press.

23. Manente, M. \& Zanette, M. (2010) Macroeconomic Effects of a VAT Reduction in the Italian Hotels \& Restaurants Industry. Economic Systems Research. 22 (4), 407-425. doi:10.1080 /09535314.2010.526927

24. Ministry for the Economy, Industry and Employment France. (2010). Bilan de la baisse de TVA dans la restauration. Retrieved February 6, 2015, from http://www.economie.gouv. fr/presse/dossiers_de_presse/20100630_Bilan_TVA_restauration.pdf.

25. Ministére de $1^{\prime}$ Artisandat, du Commerce et du Tourisme. (2012). Bilan du contrat d'avenir dans la restauration. Retrieved February 6, 2015, from http://proxy-pubminefi.diffusion.finances. gouv.fr/pub/document/18/13667.pdf

26. Newbold, P., Carlson, W. L., \& Thorne, B. (2013). Statistics for Business and Economics. Harlow: Pearson Education. 
27. Platteeuw, Ch., \& Pestana, P. (2011). Quick Reference to European VAT Compliance. Alphen aan den Rijn: Kluwer Law International.

28. Randová, K., \& Krajňák, M. (2012). Value Added Tax Rates Applied at the Restaurant Services. In Proceedings of the 1st WSE AS International Conference on Finance, Accounting and Auditing. (pp. 240-245). Zlin: WSEAS Press.

29. Randová, K. \& Krajňák, M. (2013). Value Added Tax Rates and Pricing Policy of the Selected Labour-Intensive Services Suppliers. In Proceedings of the 6th International Scientific Conference on Finance and the Performance of Firms in Science, Education, and Practice. (pp. 610-620). Zlin: Tomas Bata University in Zlin.

30. Randová, K., Krajňák, M., \& Friedrich, V. (2013). Impact of Reduced VAT Rate on the Behavior of the Labour-intensive Services Suppliers. International Journal of Mathematical Models and Methods in Applied Sciences. 7 (5), 508-518.

31. Schenk, A., \& Oldman, O. (2007). Value Added Tax. A Comparative Approach. New York: Cambridge University Press. doi:10.1017/CBO9780511618048

32. Sobotovičová, Š., Blechová, B., \& Janoušková, J. (2013). The Issue of Treshold Limit Value for VAT Registration in the Czech Republic in the Context of the Current Legislative Regulation in the EU. In Proceedings of the 5 th International Conference on Applied Economics, Business and Development (AEBD 13). (pp. 203 - 208). Greece: WSEAS Press.

33. Sudman, S. (1976). Applied Sampling. New York: Academics Press.

34. Tait, A. (1988). Value Added Tax. International Practice and Problems. Washington, D.C.: IMF.

35. Tot, A. \& Detelj, K. (2014). Implementation of Cash Transaction Fiscalization Procedure in Business: Case of Croatia. In Central European Conference on Information and Intelligent Systems, (pp. 48 - 55). Varaždin: Faculty of Organization and Informatics.

\section{Contact information}

Ing. Katerina Krzilkallová, Ph.D.

VSB - Technical University of Ostrava, Faculty of Economics

Sokolska tr. 33, 70121 Ostrava, Czech Republic

E-mail: katerina.krzikallova@vsb.cz.

Ing. Regina Strílková

VSB - Technical University of Ostrava, Faculty of Economics

Sokolska tr. 33, 70121 Ostrava, Czech Republic

E-mail: regina.strilkova@vsb.cz. 